\title{
STUDI STRUKTUR SERAT AGAVE MENGGUNAKAN FOURIER TRANSFORM INFRARED SPECTROSCOPY
}

\author{
Neng Nenden Mulyaningsih ${ }^{1}$, Fita Widiyatun $^{2}$, Nurfidah Dwitiyanti $^{2}$ \\ Pendidikan Fisika, Universitas Indraprasta PGRI ${ }^{1}$ \\ Informatika, Universitas Indraprasta PGRI ${ }^{2}$ \\ nenk_nen@yahoo.com
}

Submitted May 20, 2019; Revised September 23, 2019; Accepted November 1, 2019

\begin{abstract}
Abstrak
Tanaman agave merupakan tanaman hias yang umumnya tumbuh liar di pekarangan atau lahan kosong. Selain sebagai tanaman hias, tanaman agave memiliki banyak kegunaan dan manfaat. Pemanfaatan tanaman agave terletak pada serat tanamannya. Salah satu manfaat serat agave adalah sebagai bahan yang digunakan untuk membuat suatu material komposit untuk aplikasi dalam bidang medis atau bidang industri. Tujuan dari penelitian ini adalah untuk mengetahui karakteristik serat dari tanaman agave meliputi kristalinitas dan tingkat keteraturan serat agave dengan pengujian menggunakan Fourier Transform Infrared (FTIR) Spectroscopy. Karakterisasi dengan FTIR dapat diperoleh informasi gugus $\mathrm{C}-\mathrm{O}$ stretching selulosa 1 dan sesulosa 2, gugus aromatic $\mathrm{C}-\mathrm{H}$, gugus $\mathrm{C}=\mathrm{C}$ stretching aromatic ring $(\mathrm{G})$, gugus $\mathrm{C}=\mathrm{C}$ stretching aromatic ring $(\mathrm{S})$ dan gugus $\mathrm{OH}$ dari serat Agave. Serat Agave dibuat dalam dua jenis sampel yang berbeda. Sampel pertama yaitu serat murni tanpa perlakuan disebut (UT) dan sampel kedua yaitu serat dengan perendaman natrium hidroksida $(\mathrm{NaOH})$ disebut serat perlakuan $(\mathrm{T})$. Hasil yang diperoleh menunjukkan bahwa serat $\mathrm{T}$ mempunyai derajat kristalinitas dan tingkat kekuatan berdasarkan gugus $\mathrm{OH}$ yang lebih tinggi dibandingkan dengan serat UT.
\end{abstract}

Kata Kunci : serat, agave, Fourier Transform Spectroscopy

\begin{abstract}
Agave plants are ornamental plants that generally grow wild in the yard or empty land. Apart from being an ornamental plant, agave plants have many uses and benefits. The use of agave plants is located on the plant fibers. One of the benefits of agave fiber is the material used to make a composite material for applications in the medical or industrial fields. The purpose of this study was to determine the fiber characteristics of agave plants including the crystallinity and regularity of agave fibers by testing using Fourier Transform Infrared (FTIR) Spectroscopy. Characterization with FTIR can be obtained information of $C$ - $O$ stretching cellulose 1 and sesulose 2 groups, $C$ - $H$ aromatic groups, $C=C$ stretching aromatic ring $(G)$ groups, $C=C$ stretching aromatic ring $(S)$ groups and $\mathrm{OH}$ groups from Agave fibers. Agave fibers are made in two different types of samples. The first sample is pure fiber without treatment called (UT) and the second sample, namely fiber with soaking sodium hydroxide $(\mathrm{NaOH})$ is called treatment fiber $(\mathrm{T})$. The results obtained show that $T$ fibers have a degree of crystallinity and strength based on higher OH groups compared to UT fibers.
\end{abstract}

Key Words : fiber, agave, Fourier Transform Spectroscopy

\section{PENDAHULUAN}

Tanaman Agave tumbuh subur di berbagai wilayah di Indonesia. Tidak perlu perawatan khusus untuk menanam tanaman Agave, bahkan tanaman ini sering tumbuh liar di pekarangan atau lahan kosong. Pemanfaatan tanaman Agave di Indonesia baru sebatas sebagai tanaman hias. Padahal, tanaman ini sangatlah berguna dan bermafaat. Pemanfaatan tanaman ini telah dikembangkan di Negara Barat, terutama Amerika dan Afrika [1]. Lebih dari 200 jenis tanaman agave yang telah diketahui [2,3]. Tanaman Agave termasuk dalam kelas Liliopsida (monokotil/berkeping satu). Tanaman hias 
ini termasuk semak yang kuat dengan bentuk tajuk $\mathrm{V}$ semu. Tanaman Agave tidak memiliki akar tunggang, hanya akar lateral, dan banyak akar halus. Daun tanaman berwarna hijau atau kuning-hijau dengan bentuk linear-lanset, runcing pada ujungnya, dan berdaging dengan serat seperti benang paralel. Lebar daun dapat mencapai $25 \mathrm{~cm}$ lebar, memiliki duri marjinal pada bagian ujungnya. Bunga terminal mengandung banyak jumbai, harum, putih, putih-kehijauan, hijaukekuningan, atau pucat hijau-kebiruan, panjang bunga 2,5-3,3 cm dengan 1,0-1,8 $\mathrm{cm}$ lebar. Bunga membuka sedikit demi sedikit dalam beberapa minggu $[4,5]$.

Pada umumnya pemanfaatan tanaman Agave adalah pada serat tanamannya [6]. Banyak penelitian yang telah dilakukan untuk serat dari agave. Serat alam, merupakan salah satu bahan yang yang digunakan untuk membuat suatu material komposit $[7,8,9]$. Hal ini dikarenakan serat alam mempunyai beberapa keunggulan, diantaranya mempunyai densitas yang rendah, mudah diuraikan, tidak mudah patah, dll. [10,11,12].

Penelitian tenang agave telah banyak dilakukan dan dikembangkan, terutama penelitian tentang serat dari agave. [13] meneliti tentang sifat mekanik dari komposit matriks polimer polyester yang diperkuat dengan serat agave. [14] pernah melakukan penelitian tentang pembuatan serat nano dari agave sisalana dan bambu betung. Serat nano tersebut dibuat sebagai penguat bahan komposit untuk aplikasi komponen otomotif.

Penelitian ini adalah untuk mengetahui karakteristik dari tanaman agave yang tumbuh liar di pekarangan sekitar rumah. Karakteristik dan analisis yang dilakukan adalah untuk mengetahui sifat derajat kristalinitas dan tingkat keteraturan serat agave dengan pengujian menggunakan Fourier Transform Infrared (FTIR) Spectroscopy.

\section{METODE PENELITIAN}

Penelitian yang dilakukan merupakan penelitian eksperimen untuk mendapatkan data secara kualitatif dan data kuantitatif. Tahapan penelitian meliputi persiapan sampel dan karakterisasi sampel. Bahanbahan yang digunakan dalam penelitian yaitu daun Agave dari spesies Agave americana, air, $\mathrm{NaOH}$ dan $\mathrm{HCl}$. Sedangkan peralatan yang digunakan diantaranya pisau, gunting, garfu, pipet, sudip, gelas ukur, sendok.

Serat Agave dibuat dalam dua jenis sampel yang berbeda. Sampel pertama yaitu serat murni tanpa perlakuan disebut (UT) dan sampel kedua yaitu serat dengan perendaman natrium hidroksida $(\mathrm{NaOH})$ disebut serat perlakuan (T). Preparasi serat UT yaitu sebagai berikut: daun Agave dipotong dari pohonnya, kemudian digunting bagian pinggirnya untuk menghilangkan bagian yang berdurinya. Selanjutnya dijemur di bawah sinar matahari langsung selama 2 hari, untuk menghilangkan getah yang berlebihan. Tahap selanjutnya, daun direndam dalam air selama 2 minggu pada suhu ruang. Daun dirajut secara manual kemudian dipukuli untuk menghilangkan dagingnya. Serat yang dihasilkan kemudian dicuci dan disisir untuk membebaskan daging daun yang tersisa, kemudian disimpan di tempat kering selama dua hingga tiga hari pada suhu kamar. Sampel serat siap untuk dikarakterisasi.

Preparasi sampel $\mathrm{T}$ yaitu sebagai berikut: serat Agave mentah dicuci dengan air selama tiga hingga empat kali untuk menghilangkan sisa-sisa tanaman dan dikeringkan pada suhu kamar selama 48 jam. Serat mentah direndam dalam larutan natrium hidroksida $(\mathrm{NaOH}) 5 \%$ selama 30 menit, kemudian dicuci dengan asam klorida encer $(\mathrm{HCl})$ untuk menghilangkan kelebihan alkali. Selanjutnya, serat dibilas dengan air dingin dua atau tiga kali. 
Setelah dibilas, serat dikeringkan pada suhu kamar selama 2-3 hari. Sampel siap untuk dikarakterisasi.

Kedua sampel serat Agave UT dan T dikarakterisasi dengan FTIR pada jangkauan bilangan gelombang 400-4000 $\mathrm{cm}^{-1}$. Spektra FTIR disajikan dalam kurva hubungan antara persentase absorbansi dengan bilangan gelombang. Pengolahan data FTIR dilakukan dengan menggunakan aplikasi Origin 6.0.

\section{HASIL DAN PEMBAHASAN}

Gambar 1 menunjukkan spektra infra merah (IR) untuk serat agave murni (UT) dan serat agave perlakuan (T). Berdasarkan gambar terlihat bahwa pada rentang bilangan gelombang $400-4000 \mathrm{~cm}^{-1}$ dapat dibagi menjadi dua bagian. Bagian pertama yaitu zona kiri dengan bilangan gelombang dari 400-2000 $\mathrm{cm}^{-1}$ dan zona dua yaitu bagian kanan dengan zona bilangan gelombang lebih dari $2000 \mathrm{~cm}^{-1}$. Zona pertama mempunyai puncak khas yang lebih banyak dibandingkan dengan zona kedua. Pada Zona kedua terdapat puncak gugus $\mathrm{CH}$ alkana pada kisaran bilangan gelombang $2900 \mathrm{~cm}^{-1}$ pada serat UT lebih rendah serapannya. Hal ini membuktikan keberadaan karbon jenuh, sedangkan pita di atas $3000 \mathrm{~cm}^{-1}$ menunjukkan adanya karbon yang tidak dikenal. Puncak bilangan gelombang antara 3200 dan 3700 $\mathrm{cm}^{-1}$ terlihat lebih lebar pada kedua jenis sampel. Puncak ini merupakan puncak ikatan hidrogen. Lebarnya puncak hidrogen menunjukkan bahwa serat UT dan $\mathrm{T}$ masih mengandung kadar air yang cukup tinggi. Serat Agave perlakuan (T) mempunyai kandungan air yang lebih tinggi dibandingkan serat Agave UT. Kondisi ini terjadi karena proses perlakuan perendaman dengan $\mathrm{NaOH}$ menyebabkan serat lebih tinggi kandungan $\mathrm{OH}-n y a$.

Zona pertama (bilangan gelombang di bawah $2000 \mathrm{~cm}^{-1}$ ) mempunyai beberapa puncak serapan yang berbeda. Pada bilangan gelombang sekitar $1600 \mathrm{~cm}^{-1}$ terdapat puncak milik karbon dengan ikatan rangkap dua. Pada bilangan gelombang antara 1100-1300 $\mathrm{cm}^{-1}$ merupakan puncak milik C-O.

Untuk lebih jelas, spektra FTIR digambarkan pada puncak bilangan gelombang yang khas yaitu untuk puncakpuncak pada bilangan gelombang 850$1200 \mathrm{~cm}^{-1}, 1200-1550 \mathrm{~cm}^{-1}, 1550-1800 \mathrm{~cm}^{-}$ 1 dari zona pertama dan pada bilangan gelombang 2800-3800 $\mathrm{cm}^{-1}$ untuk gugus hidroksil dari zona kedua. Di samping itu, untuk mengetahui total serapan dan semua puncak-puncak khas dilakukan dekonvolusi dengan Aplikasi Origin 6.0. Cuplikan masing-masing puncak tersebut dapat dilihat pada Gambar 2 sampai Gambar 5.

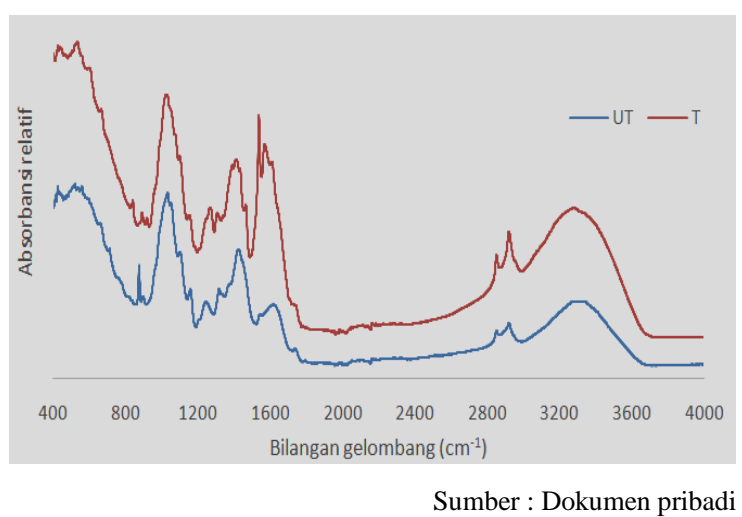

Gambar 1. Spektra IR dari serat agave UT dan $T$ pada bilangan gelombang 400-4000 $\mathrm{cm}^{-1}$

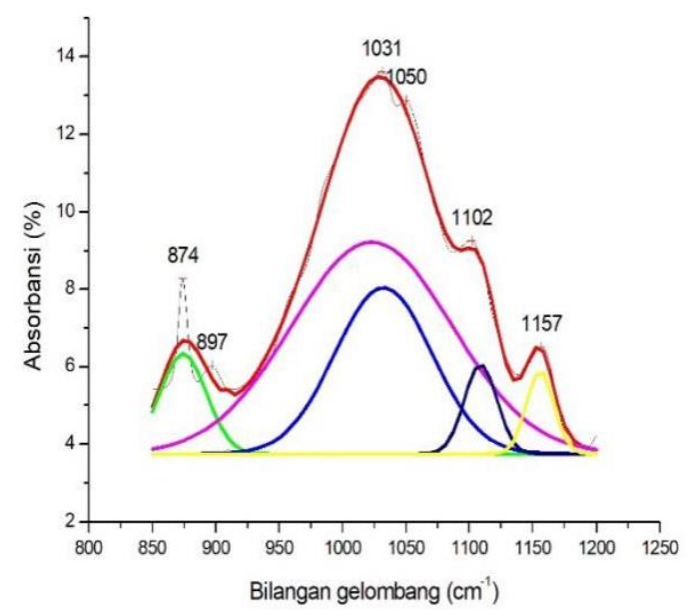


(a)

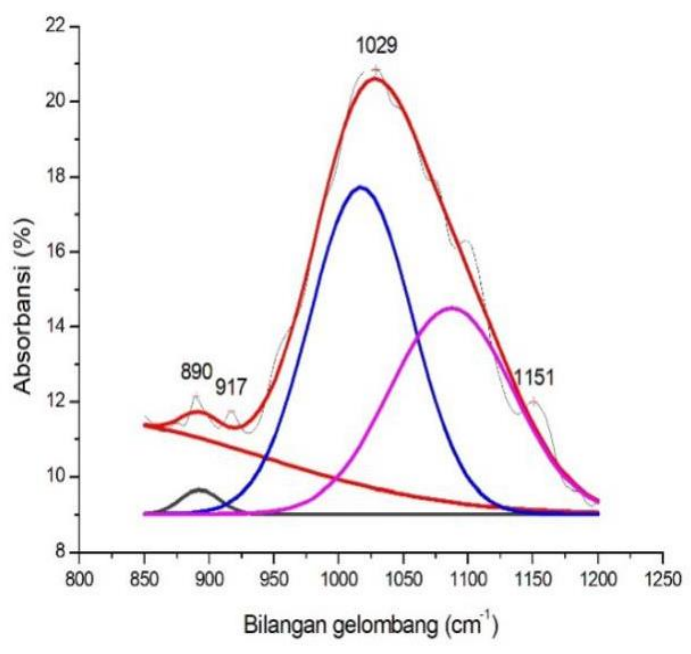

(b)

Sumber : Dokumen pribadi

\section{Gambar 2. Cuplikan spektra IR dari serat agave (a) UT dan (b) T pada bilangan gelombang $850-1200 \mathrm{~cm}^{-1}$}

Berdasarkan Gambar 2, serat Agave yang diberi perlakuan $\mathrm{NaOH}(\mathrm{T})$ mempunyai struktur yang lebih mengkristal. Hal tersebut ditandai dengan adanya gugus puncak yang hilang yaitu pada bilangan gelombang $1050 \mathrm{~cm}^{-1}$ milik gugus C-O stretching selulosa 1 dan sesulosa 2 , serta pada bilangan gelombang $1102 \mathrm{~cm}^{-1}$ milik gugus aromatic $\mathrm{C}-\mathrm{H}$. Nilai luas masingmasing puncak kedua sampel pada bilangan gelombang antara $850-1200 \mathrm{~cm}^{-1}$ ditunjukkan pada Tabel 1 dan Tabel 2.

Table 1. Nilaispektra IR dari serat agave UT pada bilangan gelombang $850-1200 \mathrm{~cm}^{-1}$

\begin{tabular}{ccccc}
\hline \multicolumn{1}{c}{ Puncak } & Area & Center & Width & Height \\
\hline 1 & 119.57 & 847.20 & 36.79 & 2.59 \\
2 & 9.48 & 909.67 & 0.20 & 37.05 \\
3 & 867.59 & 1023.20 & 126.42 & 5.48 \\
4 & 411.86 & 1032.30 & 76.44 & 4.29 \\
5 & 74.76 & 1109.00 & 25.77 & 2.31 \\
6 & 58.54 & 1155.90 & 21.83 & 2.13 \\
\hline
\end{tabular}

Table 2.Nilaispektra IR dari serat agave $T$ pada bilangan gelombang 850-1200 $\mathrm{cm}^{-1}$

\begin{tabular}{ccccc}
\hline Puncak & Area & Center & Width & Height \\
\hline 1 & 884.60 & 799.82 & 282.20 & 2.50 \\
2 & 24.37 & 892.87 & 30.15 & 0.64 \\
3 & 859.69 & 1017.40 & 78.72 & 8.71 \\
4 & 650.70 & 1087.10 & 94.63 & 5.49 \\
\hline \multicolumn{4}{c}{ Sumber : Dokumen pribadi }
\end{tabular}

Perbandingan luas kurva pada kisaran bilangan gelombang $909 \mathrm{~cm}^{-1}$ dengan 1023 $\mathrm{cm}^{-1}$ pada serat UT sebesar 0,01 , sedangkan perbandingan luas kurva pada kisaran bilangan gelombang $892 \mathrm{~cm}^{-1}$ dengan $1017 \mathrm{~cm}^{-1}$ pada serat $\mathrm{T}$ sebesar 0,03. Nilai yang lebih tinggi pada Agave $\mathrm{T}$ menunjukkan bahwa masih adanya fasa amorf dalam serat.

Gambar 3 menunjukkan cuplikan spektra IR pada bilangan gelombang antara 1200$1550 \mathrm{~cm}^{-1}$. Serat Agave UT memiliki puncak pada bilangan gelombang $1316 \mathrm{~cm}^{-}$ ${ }^{1}$ milik $\mathrm{CH}_{2}$ seslulosa 1 dan selulosa 2 yang hilang setelah serat Agave dilakukan perendaman dengan $\mathrm{NaOH}$ (sampel $\mathrm{T}$ ). Pada spektra IR serat Agave $\mathrm{T}$ muncul puncak baru pada bilangan gelombang $1523 \mathrm{~cm}^{-1}$ yang merupakan milik gugus $\mathrm{C}=\mathrm{C}$ mode stretching aromatic cincin $(\mathrm{G})$.

Perbandingan luas antara bilangan gelombang $1245 \mathrm{~cm}^{-1}$ dengan $1425 \mathrm{~cm}^{-1}$ pada serat Agave $\mathrm{T}$ sebesar 0,01 dan perbandingan luas antara bilangan gelombang $1268 \mathrm{~cm}^{-1}$ dengan bilangan gelombang $1412 \mathrm{~cm}^{-1}$ pada serat Agave T sebesar 0,51. Data luar untuk masingmasing puncak pada bilangan gelombang antara $1200-1550 \mathrm{~cm}^{-1}$ dapat dilihat pada Tabel 3 dan Tabel 4.

Puncak pada bilangan gelombang antara 1550-1800 $\mathrm{cm}^{-1}$ ditunjukkan pada Gambar 4. Dari gambar terlihat bahwa pada serat Agave $\mathrm{T}$ muncul puncak baru pada bilangan gelombang $1571 \mathrm{~cm}^{-1}$ yang 
merupakan milik gugus $\mathrm{C}=\mathrm{C}$ stretching aromatic ring $(\mathrm{G})$. Luas masing-masing puncaknya ditunjukkan pada Tabel 5 dan Tabel 6. Luas puncak pada bilangan gelombang $1604 \mathrm{~cm}^{-1}$ untuk serat Agave UT sebesar 622,28 pixel, sedangkan untuk serat Agave $\mathrm{T}$ pada bilangan gelombang $1605 \mathrm{~cm}^{-1}$ sebesar 1481.30 pixel. Sampel $\mathrm{T}$ memiliki luas yang lebih besar dibandingkan dengan sampel UT yang menandakan bahwa kandungan gugus $\mathrm{C}=\mathrm{C}$ stretching aromatic ring $(\mathrm{S})$ pada serat $\mathrm{T}$ lebih tinggi.

Gugus hidroksil pada bilangan gelombang antara 2800-3800 $\mathrm{cm}^{-1}$ ditunjukkan pada Gambar 5. Pada serat Agave UT dan T mempunyai puncak yang sama, tetapi dengan intensitas luas yang berbeda. Pada tiga puncak yang diamati yaitu puncak pada bilangan gelombang $2852 \mathrm{~cm}^{-1}, 2921$ $\mathrm{cm}^{-1}$ dan $3289 \mathrm{~cm}^{-1}$, serat Agave T mempunya intensitas luas yang lebih besar seperti ditunjukkan pada Tabel 7 dan 8 . Besarnya luas pixel menunjukkan tingginya kadar air dalam serat Agave T. Hal ini terjadi karena serat Agave $T$ mengalami perendaman yang lebih lama. Tingginya gugus $\mathrm{OH}$ pada serat Agave $\mathrm{T}$ menjadikan kualitas serat akan lebih kuat jika diaplikasikan untuk keperluan yang lebih lanjut.

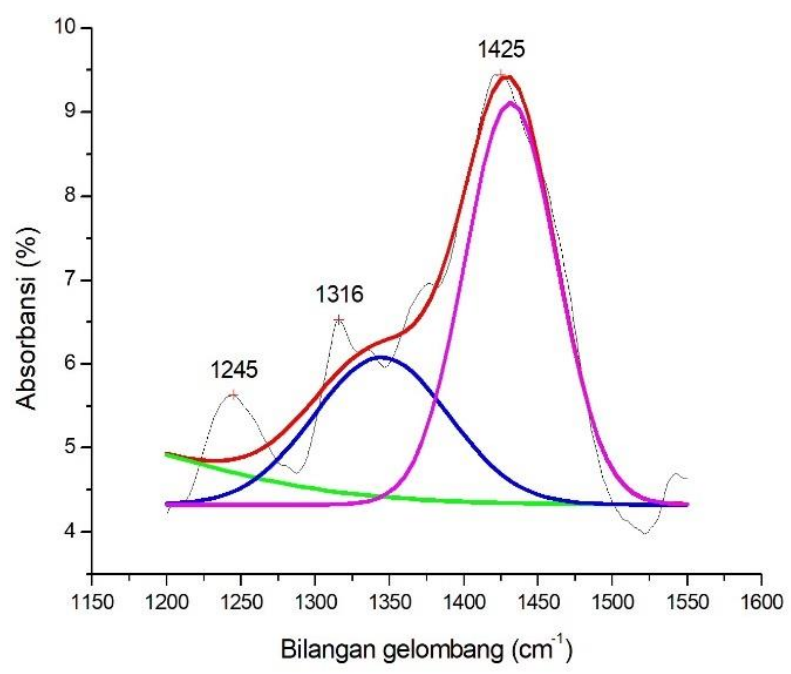

(a)

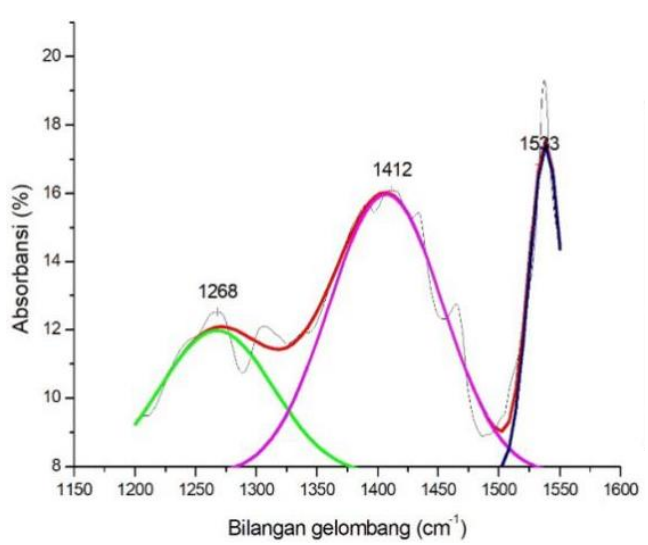

(b)

Sumber : Dokumen pribadi

Gambar 3. Cuplikan spektra IR dari serat agave (a) UT dan (b) T pada bilangan gelombang 1200$1550 \mathrm{~cm}^{-1}$

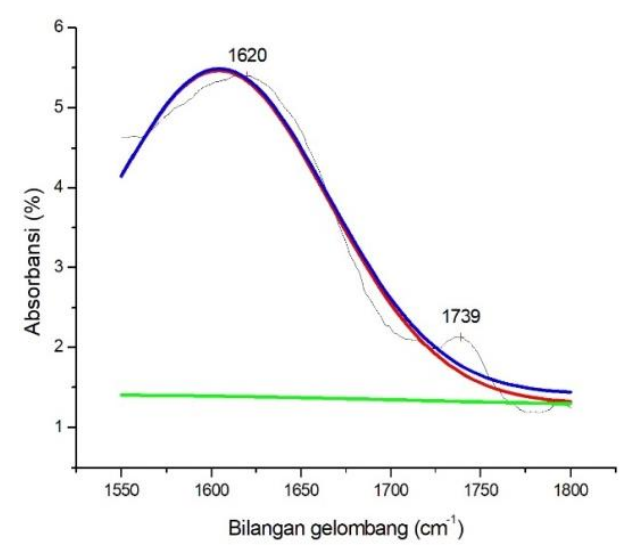

(a)

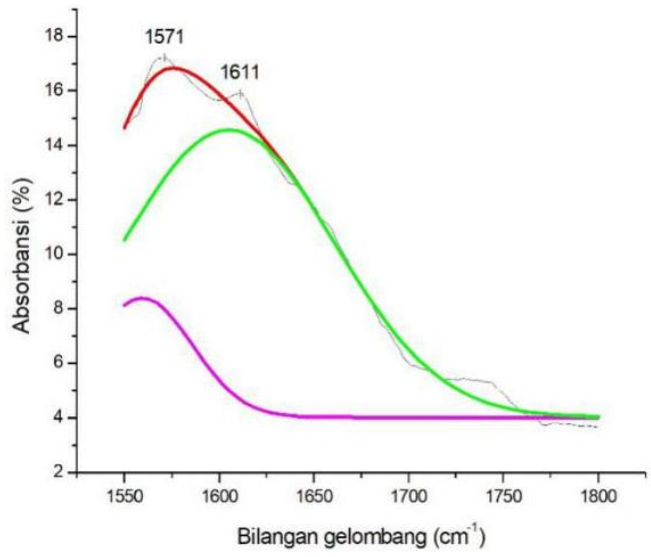

(b)

Sumber : Dokumen pribadi Gambar 4. Cuplikan spektra IR dari serat agave (a) UT dan (b) T pada bilangan gelombang 1550$1800 \mathrm{~cm}^{-1}$ 


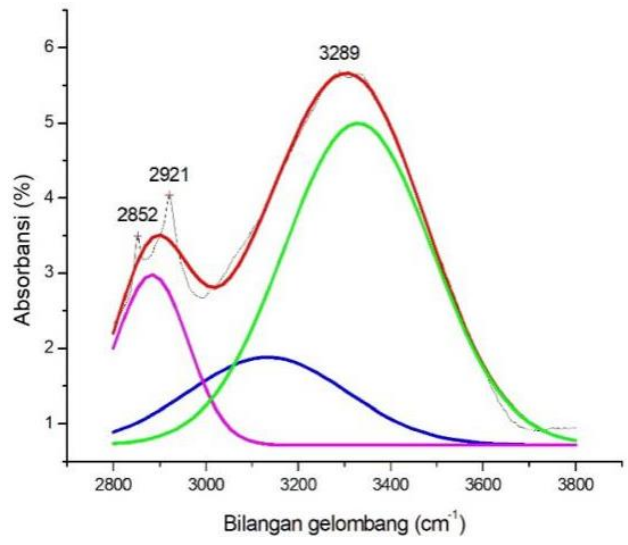

(a)

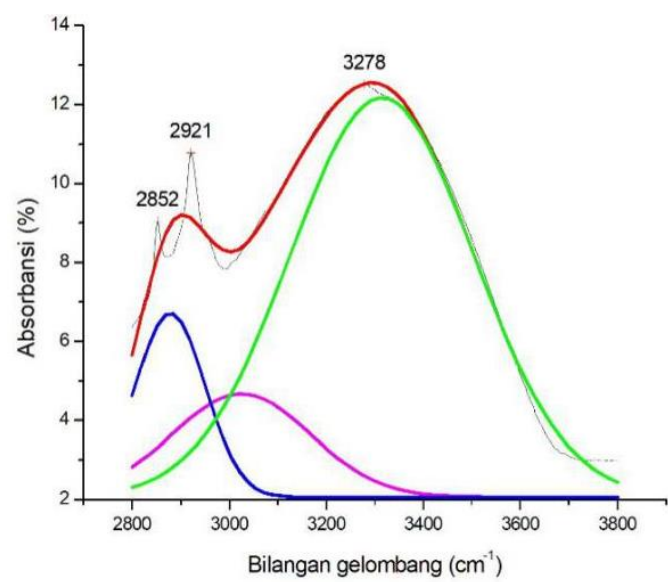

(b)

Sumber : Dokumen pribadi Gambar 5. Cuplikan spektra IR dari serat agave (a) UT dan (b) T pada bilangan gelombang 2800$3800 \mathrm{~cm}^{-1}$

Table 3. Nilai spektra IR dari serat agave UT pada bilangan gelombang $1200-1550 \mathrm{~cm}^{-1}$

\begin{tabular}{ccccc}
\hline Puncak & Area & Center & Width & Height \\
\hline 1 & 2.29 & 1256.90 & 9.72 & 0.19 \\
2 & 247.19 & 1338.50 & 120.78 & 1.63 \\
3 & 359.00 & 1430.90 & 63.41 & 4.52 \\
\hline \multicolumn{4}{c}{ Sumber : Dokumen pribadi }
\end{tabular}

Table 4. Nilai spektra IR dari serat agave $T$ pada bilangan gelombang $1200-1550 \mathrm{~cm}^{-1}$

\begin{tabular}{ccccc}
\hline Puncak & Area & Center & Width & Height \\
\hline 1 & 492.93 & 1268.2 & 92.992 & 4.2294 \\
2 & 965.38 & 1412.0 & 93.570 & 8.2319 \\
3 & 322.95 & 1523.4 & 26.716 & 9.6452 \\
\hline \multicolumn{4}{c}{ Sumber : Dokumen pribadi }
\end{tabular}

Tabel 5. Nilai spektra IR dari serat agave UT pada bilangan gelombang $1550-1800 \mathrm{~cm}^{-1}$

\begin{tabular}{ccccc}
\hline Puncak & Area & Center & Width & Height \\
\hline 1 & 622.28 & 1604.60 & 121.99 & 4.07 \\
2 & 55.96 & 1878.80 & 274.13 & 0.16 \\
\hline \multicolumn{3}{c}{ Sumber : Dokumen pribadi }
\end{tabular}

Tabel 6. Nilai spektra IR dari serat agave $T$ pada bilangan gelombang $1550-1800 \mathrm{~cm}^{-1}$

\begin{tabular}{ccccc}
\hline Puncak & Area & Center & Width & Height \\
\hline 1 & 290.50 & 1559.30 & 52.95 & 4.38 \\
2 & 1481.30 & 1605.00 & 111.90 & 10.56 \\
\hline \multicolumn{4}{c}{ Sumber : Dokumen pribadi }
\end{tabular}

Tabel 7.Nilai spektra IR dari serat agave UT pada bilangan gelombang $2800-3800 \mathrm{~cm}^{-1}$

\begin{tabular}{ccccc}
\hline Puncak & Area & Center & Width & Height \\
\hline 1 & 500.84 & 3133.7 & 343.33 & 1.1639 \\
2 & 443.19 & 2883.0 & 156.25 & 2.2632 \\
3 & 1726.2 & 3329.1 & 321.60 & 4.2828 \\
\hline \multicolumn{4}{c}{ Sumber : Dokumen pribadi }
\end{tabular}

Tabel 8.Nilai spektra IR dari serat agave $T$ pada bilangan gelombang $2800-3800 \mathrm{~cm}^{-1}$

\begin{tabular}{ccccc}
\hline Puncak & Area & Center & Width & Height \\
\hline 1 & 935.20 & 3024.5 & 285.88 & 2.6101 \\
2 & 837.61 & 2878.2 & 143.40 & 4.6605 \\
3 & 4796.4 & 3314.6 & 378.60 & 10.108 \\
\hline \multicolumn{4}{c}{ Sumber : Dokumen pribadi }
\end{tabular}

\section{SIMPULAN}

Penelitian tentang analisis FTIR terhadap serat agave yang diberikan perlakuan dengan perendaman $\mathrm{NaOH}(\mathrm{T})$ dan serat murni tanpa perlakuan (UT), diperoleh hasil bahwa serat $\mathrm{T}$ mempunyai derajat kristalinitas dan tingkat kekuatan berdasarkan gugus $\mathrm{OH}$ lebih tinggi apabila dibandingan dengan serat UT.

\section{UCAPAN TERIMAKASIH}

Ucapan terimakasih ditujukan kepada Universitas Indraprasta PGRI Jakarta melalui LPPM Universitas Indraprasta PGRI atas dana hibah penelitian DIPA Unindra sesuai kontrak penelitian Surat Perjanjian Pelaksanaan Tugas Penelitian Semester Genap Tahun 2019 Nomor: 0357/SP3/KP/LPPM/UNINDRA/III/2019. 


\section{DAFTAR PUSTAKA}

[1] Castañeda-Nava JJ, RodríguezDomínguez JM, Camacho-Ruiz RM, Gallardo-Valdez J, Villegas-García E, Gutiérrez-Mora A. Morphological comparison among populations of Agave salmiana Otto ex Salm-Dyck (Asparagaceae), a species used for mezcal production in Mexico. Flora Morphol Distrib Funct Ecol Plants. Vol. 255. 18-23. 2019.

https://doi.org/10.1016/j.flora.2019. $\underline{03.019}$

[2] Dana A. Hackman, Nicole Giese, John S. Markowitz, Adam McLean, Steven G. Ottariano, Chris Tonelli, Wendy Weissner, Shannon Welch \& Catherine Ulbricht. Agave (Agave Americana), Journal of Herbal Pharmacotherapy, 6:2, 101-122. 2006.

DOI: 10.1080/J157v06n02_09.

[3] Espinosa-Barrera LA, Sánchez-Teyer LF, Quiroz-Moreno A, NarváezZapata JA. Identification and characterization of a new satellitelike DNA family in three Agave species. Plant Gene. Vol. 16. 8-18. 2018.

[4] Mylsamy K, Rajendran I. The mechanical properties, deformation and thermomechanical properties of alkali treated and untreated Agave continuous fibre reinforced epoxy composites. Mater Des. Vol. 32 No. 5. 3076-3084. 2011. http://dx.doi.org/10.1016/j.matdes.2 $\underline{010.12 .051}$

[5] Zuccarello B, Zingales M. Toward high performance renewable agave reinforced biocomposites: Optimization of fiber performance and fiber-matrix adhesion analysis. Compos Part B Eng. Vol. 122. 109120. 2017.

http://dx.doi.org/10.1016/j.composit esb.2017.04.011
[6] Jain D, Kamboj I, Bera TK, Kang AS, Singla RK. Experimental and numerical investigations on the effect of alkaline hornification on the hydrothermal ageing of Agave natural fiber composites. Int J Heat Mass Transf. Vol. 130. 431-439. 2019.

https://doi.org/10.1016/j.ijheatmasst ransfer.2018.10.106

[7] Torres-Tello E V., Robledo-Ortíz JR, González-García Y, Pérez-Fonseca AA, Jasso-Gastinel CF, Mendizábal E. Effect of agave fiber content in the thermal and mechanical properties of green composites based on polyhydroxybutyrate or poly (hydroxybutyrate-cohydroxyvalerate). Ind Crops Prod. Vol. 99. 117-125. 2017.

http://dx.doi.org/10.1016/j.indcrop.2 017.01.035

[8] Binoj JS, Bibin JS. Failure analysis of discarded Agave tequilana fiber polymer composites. Eng Fail Anal. Vol. 95. 379-791. 2019. https://doi.org/10.1016/j.engfailanal. 2018.09.019

[9] Geethika VN, Rao VDP. Study of Tensile Strength of Agave Americana Fibre Reinforced Hybrid Composites. Mater Today Proc. Vol. 4 No. 8. 7760-7769. 2017. https://doi.org/10.1016/j.matpr.2017 .07 .111

[10] Nesimnasi, Jorhans J.S., Boimau, K., \& M. Pell, Yeremias. Pengaruh perlakuan Alkali $(\mathrm{NaOH})$ Pada Serat Agave Cantula Terhadap Kekuatan Tarik Komposit Polyester. Lontar Jurnal Teknik Mesin Udana Vol. 2 No. 1. 2015.

[11] El Oudiani A, Msahli S, Sakli F. Indepth study of agave fiber structure using Fourier transform infrared spectroscopy. Carbohydr Polym. 164:242-248. 2017. 
http://dx.doi.org/10.1016/j.carbpol.2 $\underline{017.01 .091}$

[12] Langhorst A, Paxton W, Bollin S, Frantz D, Burkholder J, Kiziltas A, et al. Heat-treated blue agave fiber composites. Compos Part B Eng. 165: 712-724. 2019. https://doi.org/10.1016/j.composites $\underline{\text { b.2019.02.035 }}$

[13] Aprianto, G., Pasek Nugraha, I Nyoman, \& Rihendra Dantes, Kadek. Pengaruh Fraksi Volume Serat Terhadap Sifat Mekanis Komposit Matriks Polimer Polyester Diperkuat Serat Agave Sisal. Jurnal Jurusan Pendidikan Teknik Mesin (JJPTM) Vol. 5 No. 2. 2016.

[14] Subyakto, Hermiati, E., Yanto, D. H. Y., Fitria, Budiman, I., Ismadi, Masruchin, N., Subiyanto, B. Proses Pembuatan Serat Selulosa Berukuran Nano Dari Sisal (Agave sisalana) dan Bambu Betung (Dendrocalamus asper). Jurnal selulosa Vol. 44 No. 2. 2009. 